\title{
Correction to: Nitropelagius marinus gen. nov., sp. nov., Isolated From Seawater, Je-bu island, South Korea
}

\author{
Sun Hwan Jeong ${ }^{1} \cdot$ Sang Seob Lee ${ }^{1}$
}

Published online: 28 November 2018

(c) Springer Science+Business Media, LLC, part of Springer Nature 2018

\section{Correction to: Curr Microbiol (2016) 73:354-360 https://doi.org/10.1007/s00284-016-1069-x}

The bacterial nomenclature used in the original submitted and published version of this article should be revised. The name Nitropelagi marinus was changed to Nitropelagius marinus with this erratum.

The article title should be "Nitropelagius marinus gen. nov., sp. nov., Isolated From Seawater, Je-bu island, South Korea".

The corrected sentence in the "Abstract" section should be, "Based on physiological and chemotaxonomic characteristics, strain JB22 $2^{\mathrm{T}}$ should be regarded as a new genus of the family Rhodobacteraceae, for which the name Nitropelagius marinus gen. nov., sp. nov. is proposed".

The corrected sentence in the "Introduction" section should be "identified as a novel genus of the family Rhodobacteraceae, for which the Nitropelagius marinus gen. nov., sp. nov. is proposed".
In Fig. 1, the species name should be "Nitropelagius marinus JB $22^{\mathrm{T}}$ KP878554".

The corrected sentence in the "Taxonomic Conclusion" section should be "On the basis of polyphasic taxonomic analysis, strain $\mathrm{JB} 22^{\mathrm{T}}$ is considered to represent a novel genus, for which the name Nitropelagius marinus gen. nov., sp. nov. is proposed".

On page 357, the heading "Description of Nitropelagi gen. nov." should be read as "Description of Nitropelagius gen. nov." and the first sentence of this section should be read as "Nitropelagius (Ni.tro.pe.la'gi.us. N.L. pref. nitropertaining to nitrate; L. neut. n. pelagus the sea; N.L. masc. n. Nitropelagius a nitrate-reducing organism from the sea)".

The heading "Description of N. marinus sp. nov." should read as "Description of Nitropelagius marinus sp. nov." and the sentence "Nitropelagius marinus (ma.ri'nus. L. masc. adj. marinus marine)." should be added as first sentence of this section.

The original article can be found online at https://doi.org/10.1007/ s00284-016-1069-x.

Sang Seob Lee

sslee@kyonggi.ac.kr

1 Department of Life Science, Graduate School of Kyonggi University, 94-6 Iui-dong Yeongtong-gu, Suwon 433-760, Republic of Korea 